О.В.Завальнюк,

кандидат педагогічних наук, викладач НПУ імені М.П.Драгоманова

\title{
ПРОБЛЕМА ЧЕСНОСТІ Й ГУДНОСТІ У СПОРТІ ТА МОРАЛЬНЕ САМОВИХОВАННЯ СПОРТСМЕНА
}

Розглядаючи моральні аспекти спорту, варто звернути увагу на проблему чесності та гідності спортсмена. 3 одного боку, спортивна діяльність сприяє формуванню таких моральних якостей особистості, як чесність, самоповага, пошана до інших. Як зазначають А.Тер-Ованесян та I. Тер-Ованесян, опановуючи раніше недоступну складну спортивну техніку, досягаючи успіху на змаганнях, спортсмен усвідомлює свої можливості, переконується у своїй здатності долати труднощі, які потребують великих фізичних та психологічних зусиль; це сприяє формуванню почуття власної гідності та більш шанобливого ставлення до інших $[1,117]$.

Спробуємо на основі аналізу сучасного спорту висвітлити проблемні питання формування чесності та гідності й морального самовиховання спортсмена в сучасному трансформаційному суспільстві.

Наявні проблеми чесності, гідності та морального самовиховання спортсменів у сучасному спорті та їх вплив на розвиток спортивних досягнень досліджували такі науковці, як Л.В.Волков, А.А.Тер-Ованесян, В.І.Столяров, М.Я.Сараф, А.О.Тіняков, В.П.Філін і багато інших.

Згідно з М.Візитеєм, спортивне суперництво - це не тільки чесне змагання в атлетизмі, але й також атлетичне (таке, що вимагає від людини максимального напруження духовних і фізичних сил) змагання в чесності. Коли людина опиняється в ситуації, де ії самоутвердження прямо й безпосередньо, у межах їі діяльнісно-практичних проявів зустрічається з самоутвердженням іншої людини, і коли кожна сторона діє при цьому з настановою на активне подолання іншої, залишитися доброчесним (зберегти баланс любові та ворожнечі) особливо складно. Проте коли це справді, всупереч зазначеним обставинам, вдається, перед нами постає доброчесність вищої проби [2, 117].

Підвищенню позитивних емоцій спортсмена мають сприяти опанування раніше недоступною складною спортивною технікою, задоволення від спілкування $з$ партнерами по команді, досягнення поставлених цілей, успіхи на змаганнях тощо. За таких умов спорт- 
смен усвідомлює свої можливості, переконується у здатності долати труднощі, які потребують великих фізичних і психічних зусиль. Це сприяе формуванню у нього почуття власної гідності і поважного ставлення до інших. Щоб виховати позитивні емоції, потрібно створювати ситуації успіху в спортивно-тренувальній діяльності, тренер має не лише спонукати до того, щоб спортсмен відчував свій успіх та зростання, а й умів бачити та заохочувати будь-який успіх учнів у процесі тренування, спілкування, іншої спільної діяльності. Такою діяльністю можуть бути неформальні дискусії. Проведення їх із спортсменами на моральну тематику має бути невід’ємною частиною виховного процесу під час занять спортом. Важливою метою дискусій $є$ підвищення чутливості дитини до морально-етичних принципів спорту та доведення до іiі свідомості існування права вибору атлета: дотримуватися моральних принципів під час змагань або їх ігнорувати [3, 71].

Водночас спорт, особливо професійний, дає чимало прикладів відхилень від норм людської моралі, наявності подвійних стандартів. Одне з найбільш глибоких системних суперечностей культури, і спорту як їі частини, на думку М. Сарафа, полягає в тому, що професія (сфера професійної діяльності) може бути хоч і у відносній, але в незалежності від сфери суспільної моральності. А це означає, що професійна діяльність може бути (і буває) такою ж мірою вільною від гуманістичних детермінант. Для професіонала все питання полягає в умовах праці, за яких він може оптимально застосувати свої знання і вміння до здобуття найвищого результату. Ось тут-то й міститься небезпека служіння хибним богам [4].

Засадничим принципом вирішення проблеми чесності в сучасному спортивному світі вважається ідеал «Fair play». Цей англійський вислів (перекладається як «чесна, або, справедлива, гра») застосовується для позначення набору етичних, духовно-моральних принципів, на які повинні орієнтуватися спортсмени, тренери, уболівальники та інші особи, пов'язані зі спортом. Ці принципи вимагають рішучої і повної відмови від перемоги за будь-яку ціну, створення рівних умов для всіх учасників змагань, внутрішнього переконання в тому, що перемогти шляхом обману, через помилку судді, через умови, що несправедливо склалися, - означає, не перемогти взагалі. Чесна гра - пошана до партнера, до суперника, до самого себе, до суддів і глядачів, уміння лишатися скромним після перемоги і спокійно сприймати поразку [5]. 
Як зазначає А.Тіняков, одним із найважливіших чинників формування поведінкового компонента моральних якостей у спортивній діяльності є дотримання спортсменом у змаганнях та суперництві принципів «чесної гри» («Fair Play»). Згідно з Свропейською хартією спорту, дотримання відповідних принципів духовно збагачує особистість спортсмена, суспільство в цілому та зміцнюють дружбу між народами. Ці принципи грунтуються на загальнолюдських моральних цінностях, таких як чесність, благородність, повага, та виявляються в таких принципах «чесної гри», як благородство щодо суперника, ведення чесної боротьби, невживання допінгу та ін. [6, 71].

$\mathrm{X}$.Ленк розглядає чесну гру у ширшому соціальному контексті. Чесна гра як соціальна цінність і соціальна норма - родом із спорту, проте з часом набула значно більшого поширення. Вона є культурним внеском спортивної традиції в культуру протистоянь у суспільстві, стала чимось на зразок негласної чесноти в регламентованих правилами конфліктах. Проте в спорті справа сьогодні на практиці стоїть так, що орієнтовані на результат системи винагороди, в яких успіх є абсолютною цінністю, неминуче заохочують нахабні і ганебні стратегії досягнення успіху. Часто це призводить до розщеплювання моралі на «таємну мораль успіху» і «офіційну мораль збереження обличчя» серед спортсменів, організаторів, менеджерів, тренерів [7].

В. Столяров та С.Баринов також звертають увагу на суперечності, пов'язані з реалізацією принципів «Чесної гри» в сучасному спорті. Спорт, як і все сучасне життя, вельми суперечливий. Створюючи умови для прояву рицарської поведінки, спортивна боротьба i прагнення перемогти спонукають до порушення принципів чесної гри. При цьому треба враховувати, що спорт не ізольований від інших сфер життя, в яких, як правило, панує орієнтація не на гуманістичні, духовно-етичні, а на суто прагматичні, технократичні цінності, переважає прагнення до досягнення успіху за будь-яку ціну. Все це істотно позначається і на ставленні спортсменів, у тому числі юних, до принципів «Фейр плей» [8].

В свою чергу, М.Візитей та Д.Качуровський задаються питанням: чи цінує сам спортсмен принцип «чесного суперництва»? Всупереч результатам доволі численних соціологічних досліджень, відповідно до яких спортсмен постає як людина, яка цей принцип не цінує, слід стверджувати: в цілому це не так. Спортсмен не може не визнавати цей принцип, оскільки дотримання його є обов'язковою передумовою його особистісного самоутвердження. А тому, якщо 
спортсмен все ж таки в тому чи іншому епізоді змагальної боротьби, в тому чи іншому випадку свого спортивного життя діє всупереч принципу «чесного партнерства», то відбувається це лише тому, що 3 тих чи інших причин він адекватно не сприймає події, що відбувається, зокрема погоджується на перемогу, на яку не заслужив, на сурогат успіху $[9,30]$.

Х.Ленк у полеміці щодо «Чесної гри» поширення цих принципів пов'язує із загальним станом моральності суспільства, де панують подвійні стандарти. В цілому у великому спорті, а в зміненій (ослабленій) формі також і в економічній конкуренції, організаційні рамки і відповідний контроль могли б сприяти усуненню подвійної моралі публічних закликів до чесної гри і таємних ганебних прийомів або порушень правил. Одними закликами і умовляннями справі можна допомогти так само мало, як і рекламними акціями на іiі користь. Чесну гру потрібно проводити по-справжньому і серйозно. Чесність i чесна гра - дуже важливі цінності етичної орієнтації, щоб збувати ïх дешево на загальному розпродажі суспільства виживання сильних. Навпаки, ідея і принцип чесної гри, за належного контролю і регламентації, заохочення спокійнішого ставлення до гри, а особливо зважаючи на самостійний, орієнтований на переживання, рішучий настрій молодого покоління, можуть в майбутньому стати ціннісним орієнтиром і для інших сфер життя суспільства. Звичайно, потрібно бути реалістом, робити контроль ефективнішим i, можливо, навіть послабити вимоги крайнього успіху. Контроль і організація (що включають не лише санкції, але й стимули) необхідні для того, щоб перетворити проповіді на реальні норми. Це слушно як щодо обмеження швидкості на автошляхах, так і в дотриманні правил чесної гри в спорті, бізнесі і суспільстві [10].

Багато вчених і фахівців, надаючи важливого значення роз'ясненню і пропаганді принципів «Фейр плей», розуміють водночас, що навряд чи можна вирішити цю проблему однією лише просвітницькою роботою, не створивши реальних стимулів, що спонукають до орієнтації на названі принципи. Один із кроків в цьому напрямі запровадження певних форм заохочення для тих, хто демонструє справжню лицарську поведінку відповідно до принципів «Фейр плей». Як відомо, в спортивній практиці для заохочення такої поведінки спортсменів вже давно використовуються певні призи і винагороди [11].

С.Матвєєв одним із головних чинників популяризації проявів моральної поведінки в спорті, необхідності дотримання всіма уча- 
сниками спортивного руху правил чесної та справедливої гри вважає широке впровадження в практику олімпійської освіти. Окрім того, щоб популяризувати та підвищувати ефективність застосування принципів «Фейр плей» в практиці сучасного спорту, потрібно змістити акценти в діяльності суб'єктів спортивного руху з поширення негативних явищ на пропаганду позитивних прикладів. Особлива роль у цьому процесі належить комісіям зі спортивної етики НОК і засобам масової інформації $[12,17]$.

М.Сараф так обгрунтовує зміст загальних принципів спортивної етики в умовах професіоналізму. Оскільки етика регулює відносини між суб'єктами діяльності, то, на його думку, передусім спортивна етика вимагає від них створювати, підтримувати і зміцнювати спортивні стосунки (у тому числі й спортивну поведінку), що об'єктивно сприяють досягненню вищих і вищих результатів. Вона вимагає також шанобливого ставлення до партнерів i, особливо, до глядачів, як до неодмінної умови діяльності. Спортивна етика не допускає обману між учасниками спортивних стосунків. Згідно з нею, учасники спортивних стосунків мають дотримуватися корпоративної честі, тобто гідного представлення свого клубу, своєї організації, публічної демонстрації їх престижу. Слід проявляти солідарність, коли справа стосується забезпечення, захисту інтересів і прав товаришів з професії, незалежно від їх клубної і національної належності. Спортивна етика не дозволяє використовувати цінності спорту (славу, ім'я, кольори і знаки клубів) для антигуманістичних, антигромадських або злочинних цілей [13].

Щоб звернути увагу спортсменів-олімпійців на дотримання етичних норм поведінки в спортивній діяльності, НОК України розробив Кодекс честі олімпійця України - сукупність моральних принципів, якими належить керуватися спортсмену. Цей кодекс честі - фундаментальний та універсальний документ, що є нормативною основою української системи спортивного виховання та самовдосконалення. Його розроблено зі врахуванням норм і вимог Конституції України, законів, що діють у сферах освіти, фізичної культури та спорту, положень Олімпійської хартії, Етичного кодексу МОК, Антидопінгового кодексу. Норми та вимоги кодексу спрямовані на формування гармонійно розвинутої особистості 3 глибокими морально-етичними переконаннями $[14,128]$.

В сучасних умовах, коли відбувається переорієнтація навчальновиховного процесу на принципи суб' єкт-суб'єктного підходу, осо- 
бливого значення набуває моральне самовиховання спортсмена.

На думку Л.Матвєєва, становлення особистості не можливе без власної активності. Тому неправильним було б розглядати особистість лише як об'єкт виховання, не меншою мірою вона є й суб' єктом виховання, особливо самовиховання. При цьому дослідник підкреслює, що сфера фізичної культури і спорту у певному розумінні надає особливо сприятливі умови для прояву життєвої активності. Сама природа засобів фізичного виховання, необхідність регулярного подолання труднощів у процесі фізичного вдосконалення, стимулююча роль спортивних змагань і досягнень все це та багато іншого потребує посилення активності особистості й тим сприяє розвиткові останньої. Вельми суттєве значення у зв'язку з цим має оптимальне співвідношення провідної ролі вихователя, самостійності та активності вихованців. Гармонічне співвідношення спрямовуючої ролі вихователя та свідомої активності вихованців призводить до поступового переростання виховання в самовиховання. При цьому в самовихованні дістає своє логічне завершення процес становлення особистості, іiі духовного визрівання і самоствердження [15, 301-302].

Як зазначають Ю. Долинний, С. Черненко, О. Олійник, фізична культура і спорт можуть і повинні взяти на себе частково функції протистояння негативним соціальним впливам на молодь. А це, своєю чергою, вимагає переосмислення всієї методології використання фізичної культури і спорту в роботі з молоддю. Насамперед має змінитися ставлення до тих, хто навчається, перетворення їх з «об'єкта фізичного розвитку і підготовки» у «суб'єкт саморозвитку», а це можливо тільки за умов орієнтації фізичної культури на цінності й інтереси сучасної молоді $[16,212]$.

Усі зовнішні виховні впливи з боку фахівців-педагогів та колективу можуть не дати очікуваних результатів, якщо сама людина не виявить достатньої ініціативи й активності, не проявить бажання та вміння займатися самовихованням, що розуміється як творча активна діяльність особистості, спрямована на вдосконалення ії фізичних, інтелектуальних, духовних якостей, волі, наполегливості, боротьбу проти власних негативних рис та недоліків. У процесі самовиховання людина використовує різноманітні форми та методи. Величезну допомогу може надати педагог, який розкриває значення для самовиховання таких методів, як самонавіювання, вміння критично поглянути на себе ззовні, самозобов'язання, самоконтролювання 
тощо. Дуже важливо сформувати у тих людей, хто займається спортом, уявлення про ідеали $[17,111]$.

Отже, вже за своєю сутністю спортивна діяльність стимулює розвиток самостійності, власної активності, суб'єктності особистості спортсмена. 3 погляду М.Візитея, спорт у дуже концентрованій, гранично узагальненій, емоційно насиченій і специфічній формі відтворює ситуацію людського самоутвердження. Його завдання полягає в тому, щоб знову й знову повертати людину до тієї ситуації, в яку вона реально поставлена як істота, котра володіє моральною волею i як така прагне до самореалізації i самобтвердыкндяфлджујочи роль дозвільно-спортивної діяльності, показує, що ця діяльність вдосконалює у студентів мету і мотиви самовиховання, спонукає до виникнення нових потреб, розвиває емоційну сферу, вміння адекватно оцінювати вчинки свої і товаришів. Формування у студентів нових психічних особливостей спричиняє подальше ускладнення, збагачення й підвищення ефективності самовиховання. При цьому вольова активність студентства $\epsilon$ необхідним компонентом, метою, результатом, головним двигуном всього навчально-виховного процесу. Виступаючи як умова і засіб процесу самовиховання, воля, своєю чергою, загартовується, спрямовуючи потенційні резерви особистості спортсмена на розв'язання завдань самовиховання, на подолання виникаючих перешкод. Під час занять у спортивних секціях студент немовби пізнає себе 3 нових, раніше невідомих йому боків, затверджує себе в своїй свідомості. Самореалізація, самовдосконалення особистісних якостей засобами фізичної культури принципово не можлива без певного рівня самоповаги. I те, як надалі складатиметься професійна діяльність, неабиякою мірою залежить від вихідних установок молодої людини, від того, чи здатна вона виявити, використовувати або навіть створювати обставини для максимальної самореалізації [19, 288-290].

Згідно з Л. Лубишевою, люди, які пройшли «школу спорту», переконані, що спорт допоміг їм виховати віру в свої сили і можливості, а також уміло ними скористатися. Спорт учить йти на жертви заради досягнення мети. Уроки, засвоєні юними спортсменами на спортивному полі, згодом, як правило, допомагають і в житті. Багато хто із спортсменів визнає, що саме спорт зробив із них людину, здатну бути особистістю. 3 його допомогою реалізується принцип сучасного життя - «розраховувати на самого себе». Це означає, що 
досягнення успіху залежить передусім від особистих, індивідуальних якостей - честолюбства, ініціативи, працьовитості, терпіння, вольових навиків [20, 150].

Процес самовиховання спортсменів потребує певних зусиль щодо організації цього процесу з боку педагогів. Завдяки загальнопедагогічному підходу до вирішення проблем самовиховання школярів в процесі занять спортом можна зробити припущення, що керівництво процесом самовиховання з боку тренерів позашкільних спортивних установ і вчителів фізкультури загальноосвітніх шкіл має здійснюватися з використанням програм самовиховання [21].

Модернізація сучасного освітнього процесу передбачає створення такого навчально-виховного поля, яке цілеспрямовано орієнтує особу на самовизначення, саморегуляцію, саморозвиток, щоб повноцінно проявити себе в подальшій життєдіяльності, у тому числі у вирішенні основної установки для спортсмена - досягненні високого спортивного результату, а в масовому спорті саморегуляція поведінки дасть можливість підліткові уникнути впливу таких соціальних явищ, як юнацький алкоголізм, наркоманія, токсикоманія та ін. [22].

Л.Волков звертає увагу на роль спорту у розвитку самостійності та ініціативності юних спортсменів. Ці властивості виявляються тоді, коли для подолання труднощів і перешкод не можна обмежуватися застосуванням звичних засобів та методів, а допомоги ззовні немає або вона мінімальна. Як правило, вони ефективно виховуються під час проведення спортивних ігор. Тут спортсмен повинен швидко і правильно оцінити ситуацію, що виникла раптово, адекватно сприйняти інформацію, продумати і обрати доцільний план дії, прийняти самостійне рішення [23, 128].

Серед методів і прийомів, спрямованих на розв'язання завдань морального самовиховання і виховання вольових властивостей юних спортсменів, застосовуються такі загальновизнані дії, як самоспостереження, самоаналіз, самоконтроль, самопереконання, самооцінювання, самонавіювання, самонаказ, самосхвалення, самопримус, самозаспокоєння. Серйозна увага приділяється веденню щоденників самоконтролю, в яких фіксуються не лише спортивні досягнення, але й успіхи в самовихованні інтелектуальних, етичних і вольових рис особи відповідно до експериментальних програм [24].

Отже, сучасний спорт - це не тільки сфера надзвичайних спортивних досягнень, але й рутинна, повсякденна робота над собою. Велику роль у цій роботі виконує моральне самовиховання спортсмена. 


\section{ЛІТЕРАТУРА}

1. Тер-Ованесян А.А. Педагогика спорта. - К., 1986. - 208 с.

2. Визитей $Н$. О социально-культурных функциях современного спорта // Теорія і методика фізичного виховання і спорту. - 2009. - №4. - С.11-19.

3. Тіняков А.О. Аналіз можливостей юнацького спорту як соціальної системи у вихованні моральних якостей особистості // Теорія і практика управління соціальними системами : філософія, психологія, педагогіка, соціологія. - 2010. - №3. - С. 66-74.

4. Сараф М.Я. Профессионализация спорта и спортивная этика [Електронний документ] // Теория и практика физической культуры. - 2001. - №7. Режим доступу: http://lib.sportedu.ru/Press/TPFK/2001N7/p32-33.htm

5. Столяров В.И. Гуманистическая культурная ценность современного спорта и олимпийского движения [Електронний документ] // Спорт, духовные ценности, культура. - М., 1997. - Вып. 2. - С.141-314. Режим доступу: http://lib.sportedu.ru/GetText.idc?TxtID=741

6. Тіняков А.O. Аналіз можливостей юнацького спорту як соціальної системи у вихованні моральних якостей особистості // Теорія і практика управління соціальними системами : філософія, психологія, педагогіка, соціологія. - 2010. - №3. - С. 66-74.

7. Ленк $X$. Этика спорта как культура честной игры [Електронний документ] // Неприкосновенный запас. - 2004. - №3. Режим доступу: http://magazines.russ.ru/nz/2004/35/lenk21.html

8. Столяров В.И. Место принципов «Фэйр плэй» в концепции олимпизма и системе олимпийского образования [Електронний документ] // Спорт, духовные ценности, культура. - М., 1997. - Вып. 6. - С. 254 278. Режим доступу: http://lib.sportedu.ru/GetText.idc?TxtID=919

9. Візитей M. М. Спорт вищих досягнень і його соціально-культурна місія в нових умовах розвитку суспільства // Педагогіка, психологія та медико-біологічні проблеми фізичного виховання і спорту. - 2009. №12. - C. 27-31.

10. Ленк $X$. Этика спорта как культура честной игры [Електронний документ] // Неприкосновенный запас. - 2004. - №3. Режим доступу: http://magazines.russ.ru/nz/2004/35/lenk21.html

11. Столяров В.И. Место принципов «Фэйр плэй» в концепции олимпизма и системе олимпийского образования [Електронний документ] // Спорт, духовные ценности, культура. - М., 1997. - Вып. 6. - С.254 278. Режим доступу: http://lib.sportedu.ru/GetText.idc?TxtID=919

12. Матвеев $C$. Этика в спорте или «fair play»: утопия или реальность // Наука в олимпийском спорте. - 2005. - №2. - С.6-18.

13. Сараф М.Я. Профессионализация спорта и спортивная этика [Електронний документ] // Теория и практика физической культуры. - 2001. №7. Режим доступу: http://lib.sportedu.ru/Press/TPFK/2001N7/p32-33.htm 
14. Радченко Л. Проблема этики в современном олимпийском спорте // Наука в олимпийском спорте. - 2007. - №2. - С. 126-132.

15. Матвеев Л.П. Теория и методика физической культуры. - М., 1991. -543 с.

16. Долинний Ю.О. Духовність у спорті вищих досягнень // Педагогіка, психологія та медико-біологічні проблеми фізичного виховання і спорту. 2005. - № 10. - С.212-214.

17. Основы теории и методики физической культуры. - М., 1986. -352 с.

18. Визитей $H$. О социально-культурных функциях современного спорта // Теорія і методика фізичного виховання і спорту. - 2009. - №4. - С.11-19.

19. Юрчук С.М. Дозвіллєво-спортивна діяльність як один із чинників розвитку лідерських здібностей студентів // Педагогіка, психологія та медико-біологічні проблеми фізичного виховання і спорту. - 2009. №10. - С.288-291.

20. Лубышева Л.И. Социология физической культуры и спорта. - М., 2001. $-240 \mathrm{c}$.

21. Филин В.П. Теория и практика самовоспитания школьников-спортсменов [Електронний документ] // Физическая культура. Воспитание. Образование. Тренировка. - 1997. - №3. Режим доступу: http://lib.sportedu.ru/press/fkvot/1997N3/p23-26.htm

22. Сквориов Г.И. Педагогическая стратегия нравственного воспитания спортом [Електронний документ] // Физическая культура. Воспитание.

Образование. Тренировка. - 2005. - №3. Режим доступу: http://lib.sportedu.ru/press/fkvot/2005N3/p56-58.htm

23. Волков Л.В. Теория и методика детского и юношеского спорта. - К., 2002. $-295 \mathrm{c}$.

24. Филин В.П. Теория и практика самовоспитания школьников-спортсменов. [Електронний документ] // Физическая культура. Воспитание. Образование. Тренировка. - 1997. - №3. Режим доступу: http://lib.sportedu.ru/ press/fkvot/1997N3/p23-26.htm

Завальнюк О. Проблема чесності й гідності у спорті та моральне самовиховання спортсмена.

Суперництво в сучасному спорті - надзвичайно гостре питання. Іноді спортивна боротьба точиться за таку дещицю міліметрів, секунд, кілограмів, що суперники не звертають особливої уваги один на одного. В такі моменти надзвичайно актуальними виявляються моральні засади притаманної спорту змагальності. Остання, зокрема, передбачає таке суперництво, яке грунтується на чесності й гідності спортсменів. Засадничим принципом вирішення проблеми чесності в спортивних змаганнях вважається ідеал «Fair play». Водночас спорту притаманні різні відхилення від моральних норм, наявність подвійних стандартів. У зв'язку з вирішенням питань морального виховання та виховання вольових якостей спортсменів потрібно 
здійснювати загальновизнані дії (самоконтроль, самопереконання, самозаспокоєння та ін.). Звертається увага на негативні соціальні впливи на молодь, на необхідність переосмислення ролі спорту в роботі з юнаками і дівчатами. 3 метою дотримання етичних норм поведінки в спортивній діяльності розробляються спеціальні кодекси честі, норми і вимоги яких спрямовані на формування гармонійно розвиненої особистості з глибокими морально-етичними переконаннями.

Ключові слова: людина, спорт, чесність, гідність, самовиховання, самоствердження, моральні норми, суперництво.

Завальнюк Е. Проблема честности и достоинства в спорте и нравственное самовоспитание спортсмена.

Соперничество в современном спорте - чрезвычайно острый вопрос. Иногда спортивная борьба идет за такую малость миллиметров, секунд, килограммов, что соперники не обращают особого внимания друг на друга. В такие моменты очень актуальными оказываются моральные принципы присущей спорту состязательности. Последняя, в частности, предусматривает такое соперничество, которое основывается на честности и достоинства спортсменов. Основополагающим принципом решения проблемы честности в спортивных соревнованиях считается идеал «Fair play». Одновременно спорту присущи различные отклонения от моральных норм, наличие двойных стандартов. В связи с решением вопросов нравственного воспитания и воспитания волевых качеств спортсменов нужно осуществлять общепризнанные действия (самоконтроль, самоубеждение, самоуспокоение и др.). Обращается внимание на негативные социальные влияния на молодежь, на необходимость переосмысления роли спорта в работе с юношами и девушками. С целью соблюдения этических норм поведения в спортивной деятельности разрабатываются специальные кодексы чести, нормы и требования которых направлены на формирование гармонично развитой личности с глубокими нравственно-этическими убеждениями.

Ключевые слова: человек, спорт, честность, достоинство, самовоспитания, самоутверждения, моральные нормы, соперничество.

Zavalniyuk $O$. Problem of honesty and dignity in sports and moral selfeducation of a sportsman.

Rivalry in sports today as an extremely sensitive issue. Sometimes sports competition takes place for such small fractions of millimeters, seconds, kilograms, that the rivals do not pay much attention to each other. At such moments moral principles inherent in sports competition are very relevant. The latter, in particular, provides a rivalry that is based on honesty and dignity of athletes. A fundamental principle of solving the problem of honesty in sports is considered the ideal «Fair play». Simultaneously sport has various deviations from moral standards, double standards. In connection with the solution of issues of moral 
education and upbringing of volitional qualities of athletes there is a need to implement such recognized actions as self-control, self-persuasion, self-complacency, and others. Attention is drawn to the negative social impact on the youth, sport in the work with youth requires a rethinking. With the aim of compliance with ethical conduct in sport for athletes specific codes of honor, standards and requirements which are aimed at creating a harmonious personality with deep moral and ethical beliefs are being developed.

Key words: human, sport, honesty, dignity, self-education, self-affirmation, moral norms, rivalry. 